\title{
ATTRIBUTES of TOTAL PHENOLIC CONTENT, ANTIOXIDANT CAPACITY and IN-VITRO SIMULATED BIOACCESSIBILITY of ASTRINGENT, NON-ASTRINGENT and WILD (ROOTSTOCK) PERSIMMONS
}

\author{
Emine Aydin* \\ Duzce University, Faculty of Agriculture, Department of Agricultural Biotechnology, Duzce, Türkiye
}

Received / Geliş: 11.02.2021; Accepted / Kabul: 19.04.2021; Published online / Online bask1: 23.04.2021

Aydin, E. (2021). Attributes of total phenolic content, antioxidant capacity and in-vitro simulated bioaccessibility of astringent, non-astringent and wild (rootstock) persimmons. GIDA (2021) 46 (3) 669-680 doi: 10.15237 Igida.GD21032

Aydin, E. (2021). Buruk, buruk olmayan ve yabani (anaç) hurmaların toplam fenolik bileşen, antioksidant kapasite ve in-vitro simule edilmiş biyoalinabilirlik özellikleri. GIDA (2021) 46 (3) 669-680 doi: 10.15237 /gida.GD21032

\begin{abstract}
Persimmon which is widely known as "Trabzon Hurmas1" and "Cennet Meyvesi" is a very popular fruit with bright orange color. In the presented study, extractable, non-extractable, total phenolic content (TPC), antioxidant capacity (AC) and bioaccessibility of Trabzon persimmons (astringent, non-astringent and wild persimmon) were determined. The results of this study indicated that all types of persimmons have great importance both on TPC, AC and bioaccessibility. Compared to astringent and non-astringent types, the wild persimmon type had the highest TPC. Another attractive result from this study, although the wild persimmons do not prefer for consumption, the results demonstrated that the bioaccessible phenolics of this type of persimmons were found to be 6.7 fold higher than the non-astringent types and 4.7 fold higher than the astringent types. Especially the wild type of persimmon is a good source of natural antioxidant and further studies should be carried out for wild type persimmon.
\end{abstract}

Keywords: Persimmon, total phenolic, antioxidant capacity, in-vitro bioaccessibility

\section{BURUK, BURUK OLMAYAN ve YABANİ (ANAÇ) HURMALARIN TOPLAM FENOLIK BİLEŞEN, ANTİOKSİDANT KAPASİTE ve IN-VITRO SIMMULE EDİLMİŞ BİYOALINABİLİRLİK ÖZELLİKLERİ}

\section{ÖZ}

Parlak turuncu renge sahip olan hurma, Türkiye'de daha çok "Trabzon Hurması" ve "Cennet Meyvesi” olarak bilinmektedir. Bu çalışmada üç farklı çeşitte (buruk, buruk olmayan ve yabani) Trabzon hurmasının; ekstrakte, ekstrakte olmayan, toplam fenolik bileşen, antioksidan kapasite ve biyoalınabilirlikleri araştırılmıştır. Bu çalışmanın sonuçlarına göre, bütün hurma çeşitlerinde toplam fenolik bileşen, antioksidan kapasite ve biyoalınabilirlik büyük öneme sahiptir. Buruk ve buruk olmayan hurma çeşitleri ile karşılaştırıldığında, yabani hurma çeşidinin daha fazla toplam fenolik bileşen (864.85 mg GAE/100 g) içerdiği tespit edilmiştir. Bu çalışmadan elde edilen bir başka ilgi çekici sonuçta ise her ne kadar tüketim için tercih edilmese de yabani hurma çeşidinin buruk olmayan hurma çeşidinden 6.7 kat, buruk hurma çeşidinden ise 4.7 kat daha yüksek biyoalınabilirliğe sahip

\footnotetext{
* Corresponding author / Yazışmalardan sorumlu yazar:

$\triangle$ emineaydin@duzce.edu.tr 胫 (+90) 3805412294 且 (+90) 3805412295

Emine Aydin; ORCID no: 0000-0001-9635-4791
} 
olduğu tespit edilmiştir. Özellikle yabani hurma iyi bir doğal antioksidan kaynağıdır ve üzerinde daha fazla çalışma yapılmalıdır.

Anahtar kelimeler: Hurma, toplam fenolik, antioksidan kapasite, in-vitro biyoalınabilirlik

\section{INTRODUCTION}

Persimmon is cultivated in a large part of China, Korea, Japan, Turkey, Brazil, and Italy (Butt et al., 2015), which belongs to Ebenaceae family and genus Diospyros (Martínez-Calvo et al., 2013). Commonly, above 400 species of persimmon are planted worldwide. Four of them; Diospyros lotus, Diospyros kaki, Diospyros virginiana, and Diospyros oleifera (Bibi et al., 2007) have important value (Zheng et al., 2006). The D. lotus L. is used as a rootstock for D. kaki L. (Messaoudi et al., 2009) and it knows as a wild type in Turkey (Günal, 2002). This persimmon is recognized as small size (Günal, 2002) and has a bluish-black color. The D. lotus, persimmon called as "Black Persimmon", "Black Fruit", "Plum Persimmon" (Baytop, 1999) and "Wild Trabzon Persimmon" (Günal, 2002). The D. kaki was made entry from the Black Sea region to Turkey and named the "Trabzon Persimmon-Trabzon Hurmasi". It is a commercially grown persimmon type. This type of persimmon widely spread out the many parts of Turkey and called as "Fruit of Paradise-Cennet Meyvesi" (Yeşiloğlu et al., 2017). The D. kaki types point out with its bright orange color and separated into astringent and non-astringent types. While the non-astringent types can eat up in the immature form, the astringent types solely can eat up in the mature form. When the astringent type fully turn to the mature form, just like a pudding form, has the delicious taste.

According to the numerous studies on plant species; the Trabzon persimmons being one of the best plant sources based on their phenolics and antioxidant capacities (Ayaz et al., 1997; Loizzo et al., 2009). From obtained data it was clearly detected that; the relationship between TPC and AC related to the powerful correlation between them (Grygorieva et al., 2018). Phenolic substances consisted in plant foods; while phenolic acids are divided into subgroups such as flavonoids, lignans and stilbenes, especially phenolic acids and flavonoids are important as antioxidants (Harşı1t, 2015).
Polyphenolic compounds, which are found in fruits and vegetables and constitute the major and most important part of secondary plant metabolites (Sakakibar et al., 2003). The ferulic acid, p-coumaric acid, gallic acid (Yaqub et al., 2016), catechin, epicatechin, catechin epigallo and condensed proanthocyanidins are the most commonly found phenolic compounds in persimmon (Giordani et al., 2011).

Suzuki et al. (2005), determined in their study, the total phenolic substance and catechin content of 3 astringent and 2 non-astringent types of persimmon. The gallic acid, catechin, epicatechin and epigallocatechin identified in the analyzed fruits. According to these results; researchers reported that the astringent types are rich in phenolic components, and consequently these fruits can be a good source of natural antioxidants.

The astringency is caused by the phenolic compounds included in the fruit (Yönel et al. 2008), especially tannins (Macheix et al., 1990; Mehmood et al., 2016). In this context, the persimmon fruit is defined by its high amount of tannins (tannic acid) which disappears when the fruit grows mature. The persimmon has also plenty of phenolic components other than tannins, and it has been demonstrated that these compounds may reduce the risk of chronic diseases (Gorinstein et al., 1994).

In recent studies, it has been determined that the persimmon fruits have the properties of lowering both cholesterol and high blood pressure, enhancing the immune, are good for digestive system diseases and have an important place in protection from common cancer diseases. In general, the persimmon fruits have a curative effect on eliminating weakness, anaemia, vitamin deficiency and gastrointestinal diseases. This fruits interrupt diarrhea, increases the appetite, prevents the stomach gastritis and heals the intestinal inflammation (Bölek, 2013). 
Moreover, the persimmon fruit is a ideal source of vitamins such as vitamin $A$, vitamin $E$ (Tuzcu and Yildirim, 2000) and vitamin $C$ as well as the minerals such as Ca and K (Mowat, 1990). Due to all these excellent features, the fruit types such as persimmon are called the fruit of the future (Kaplankıran, 2011).

To the best of our knowledge, there has been no detailed research related to the comparison of three types of persimmon's extractable, nonextractable, TPCs, antioxidant capacities of astringent, non-astringent and wild persimmon species. Another target of this study is determination of in-vitro bioavailability of total phenolic and AC of samples. In this research author planned to explore the properties of persimmons which obtained from the same location but in different harvest time.

\section{MATERIAL AND METHODS \\ Materials}

In this study, fresh and mature varieties of the astringent, non-astringent (Diospyros kaki L.) and wild (Diospyros lotus L.) persimmons were used. Photographs of the samples can be seen in Figure 1. The three different types of persimmons used were collected from a local garden in the center of Duzce, Turkey but in a different harvest time during the autumn in 2020. The raw materials were stored at $+4{ }^{\circ} \mathrm{C}$ until analyzed.

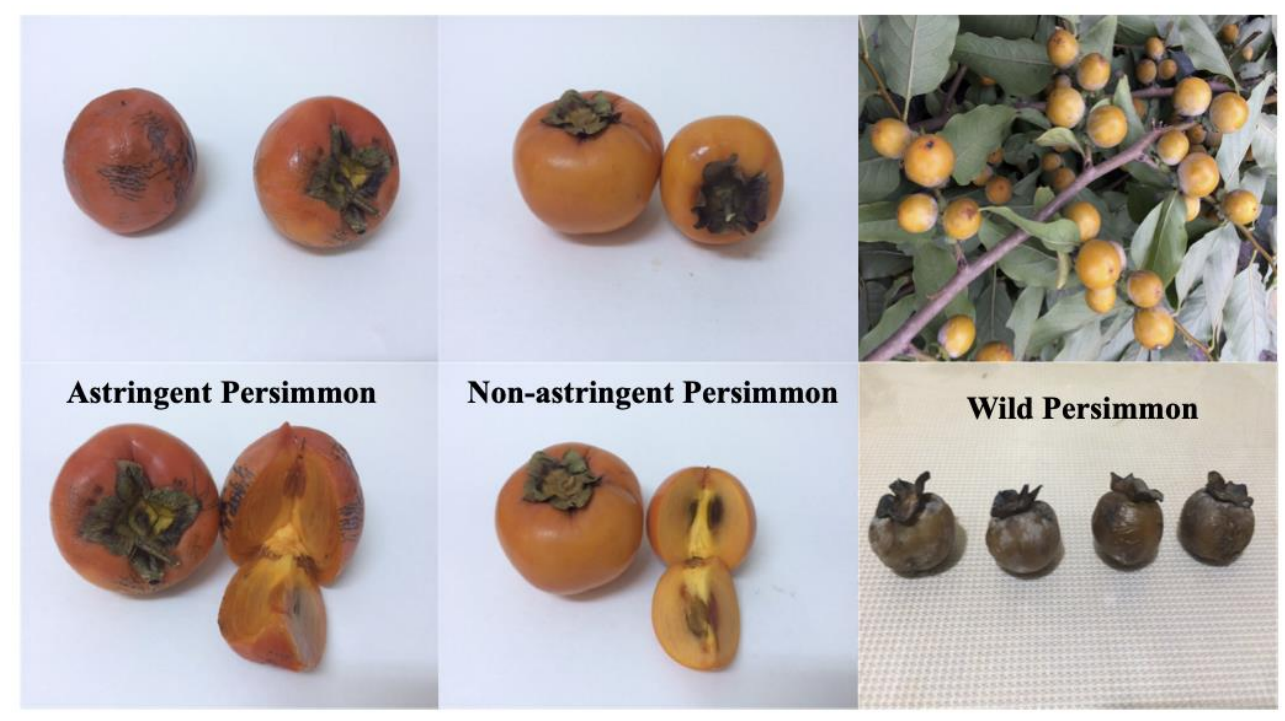

Figure 1. Photographs of persimmon samples

\section{Methods \\ Chemicals}

The Folin-Ciocalteu reagent, ethanol, methanol, ammonium acetate, sodium acetate, sodium carbonate, sodium chloride, and copper(II)chloride purchased from Merck (Germany). ABTS $^{*} \quad\left(2,2^{\prime}\right.$-azinobis(3ethylenbenzoline-6sulfonic acid) radical cation, DPPH• (2,2-diphenyl-1-picrylhydrazyl), TPTZ (2,4,6-tris(2-pyridyl)-s-triazine), Trolox (6hydroxy-2,5,7,8-tetramethylchroman-2-

carboxylic acid), bile extract, gallic acid, neocuproine, hydrochloric acid $(37 \% \mathrm{w} / \mathrm{v})$ and sulfuric acid (95-98\%), pancreatin, pepsin, potassium chloride, sodium hydroxide were purchased from Sigma-Aldrich (USA). All reagents were used for the analytical grade purity. The high-quality pure water was used to perform the analysis provided by the Milli-Q system (Millipore, USA).

\section{Extraction for extractable and non-} extractable phenolics

Extractable phenolic (EP) compounds of persimmon samples were determined to the method enhanced by Vitali et al. (2009) with minor modifications. The following procedure has been followed; two grams $(2.0 \mathrm{~g})$ of 
persimmon sample was mixed with $20 \mathrm{~mL}$ of $\mathrm{HCl}$ conc./methanol/water (1:80:10, v/v/v) and shaken with laboratory rotary shaker at $250 \mathrm{rpm}$ for $2 \mathrm{~h}$ at $20^{\circ} \mathrm{C}$. At the end of the period, the mixture was centrifuged at $4{ }^{\circ} \mathrm{C}$ for $10 \mathrm{~min}$ at 3500 $\mathrm{rpm}$ in a centrifuge (Eppendorf Centrifuge 5430R, USA). The supernatants were separated and kept at $-20^{\circ} \mathrm{C}$ (in dark condition) until experiments carried out.

To insulate the non-extractable phenolics (NEP), the residues which were obtained from the EPs were used. The residues combined with the $20 \mathrm{~mL}$ mixture of methanol $/ \mathrm{H}_{2} \mathrm{SO}_{4}$ conc. (10:1) and held in a water bath (at $85^{\circ} \mathrm{C}$ ) for $20 \mathrm{~h}$. At the end of the time, the mixtures cooled at room temperature and centrifuged at $3500 \mathrm{rpm}$ for 10 min at $4^{\circ} \mathrm{C}$ (Eppendorf Centrifuge 5430R, USA). The supernatants of EP and NEP were kept in dark condition at $-20^{\circ} \mathrm{C}$ until the analyses carried out.

\section{Determination of total phenolic content}

Total phenolic content was determined using a modified version of the Folin-Ciocalteu colorimetric procedure according to $\mathrm{Xu}$ et al. (2009). The diluted persimmon extracts $(0.5 \mathrm{~mL})$ were mixed with $2.5 \mathrm{~mL}$ deionized water and 0.5 $\mathrm{mL}$ of $1.0 \mathrm{M}$ Folin-Ciocalteu reagent and the mixture vortexed at room temperature for $10 \mathrm{~min}$. $1.5 \mathrm{~mL}$ sodium carbonate $(7.5 \%)$ was added to the mixture and blended gently for $30 \mathrm{~min}$ at room temperature. At the end of the time, the absorbance was measured at $750 \mathrm{~nm}$ with Shimadzu UV-VIS spectrophotometer. The absorbance was compared to a standard curve of gallic acid (GA). The standard curve was (0-500 $\mathrm{mg} / \mathrm{L})$ plotted using gallic acid. TPC content was calculated the sum of EPs and NEPs. The results were expressed as the $\mathrm{mg}$ of GAE/100g dw.

\section{Determination of bioaccessible phenolics}

The bioaccessible phenolics were determined via simulated digestion system. In order to achieve this, the in-vitro digestion enzymatic extraction method was used that adopted from Vitali et al. (2009) with minor modifications. To provide the digestive system, the conditions in the human gastric and gastrointestinal tract was created in this assay. According to this method, for simulating the gastric digestion, $1.0 \mathrm{~g}$ of persimmon sample was mixed with $10 \mathrm{~mL}$ distilled water and $0.5 \mathrm{~mL}$ of pepsin solution (20 $\mathrm{g} / \mathrm{L}$ in $0.1 \mathrm{~mol} / \mathrm{L} \mathrm{HCl}$ ) was added and incubated at $37^{\circ} \mathrm{C}$ in a shaking water bath for $1 \mathrm{~h}$. After then, $\mathrm{pH}$ was adjusted to 7.2 and thus simulation of gastric digestion was stopped. Additionally, the intestinal-simulated digestion was performed with the addition of $2.5 \mathrm{~mL}$ of bile/pancreatin solution $(2.0 \mathrm{~g} / \mathrm{L}$ of pancreatin and $12 \mathrm{~g} / \mathrm{L}$ of bile salt in $0.1 \mathrm{~mol} / \mathrm{L} \mathrm{NaHCO}_{3}$ ) and $2.5 \mathrm{~mL}$ of $\mathrm{NaCl} / \mathrm{KCl}$ $(120 \mathrm{mmol} / \mathrm{L} \mathrm{NaCl}$ and $5 \mathrm{mmol} / \mathrm{L} \mathrm{KCl}$ ) were added the samples and incubated in shaking water bath at $37^{\circ} \mathrm{C}$ for $2.5 \mathrm{~h}$. After incubation, the persimmon samples were centrifuged at 3500 $\mathrm{rpm} / 10 \mathrm{~min}$ and the supernatant was used for determination of bioaccessible phenolics which were stored $-18^{\circ} \mathrm{C}$ until the analyses carried out. Bioaccessible phenolics were determined using Folin-Ciocalteu spectrophotometric method and expressed as gallic acid equivalents ( $\mathrm{mg}$ of GAE $/ 100 \mathrm{~g}$ dw). Bioaccessibility was also estimated as the percentage of TPC. The bioaccessibility of antioxidants and phenolics (\%) was estimated according to Anson et al. (2009).

\section{Analysis of antioxidant capacity ABTS $^{+}$assay}

The ABTS ${ }^{+}$(2,2-azinobis-(3ethylbenzothiazoline-6-sulphonic acid)) radical cation assay was analysed described by Apak et al. (2007). To generate the ABTS ${ }^{-+}$solution, the $7 \mathrm{mM} \mathrm{ABTS}^{\cdot+}$ and $2.45 \mathrm{mM}$ potassium persulfate was mixed and incubated at room conditions for $12-16 \mathrm{~h}$ in the dark. The ABTS*+ solution was diluted with ethanol $(98 \%)$ at a range of 1:10 to dilute the blue-green color. Four $\mathrm{mL}$ ethanol and $1.0 \mathrm{~mL} \mathrm{ABTS}^{*+}$ solution was mixed and stored in the dark for $6 \mathrm{~min}$. At the end of the period the absorbance was measured at $734 \mathrm{~nm}$ ( $\left.A_{\text {blank }}\right)$ by using Shimadzu UV-VIS spectrophotometer. On the other hand, the $x \mathrm{~mL}$ extract of persimmon, (4- $x) \mathrm{mL}$ ethanol and $1 \mathrm{~mL} \mathrm{ABTS} \cdot+$ solution was mixed and kept in the dark for $6 \mathrm{~min}$. At the end of the time, the absorbance was read $\left(A_{\text {sample }}\right)$. The standard curve was plotted with using different concentrations (10-150 $\mu \mathrm{L}$ ) of Trolox. Results of AC were utilized with the calibration curve and 
estimated in $\mu \mathrm{mol}$ Trolox/g sample. The ABTS•+ radical scavenging activity was calculated with the following equality:

ABTS $\cdot \%=\left(A_{\text {blank }}-A_{\text {Sample }}\right) /\left(A_{\text {Blank }}\right) \times 100$

\section{CUPRAC assay}

CUPRAC estimation was carried out according to the method outlined by Apak et al. (2007). In order of $1.0 \mathrm{~mL} 1 \times 10^{-2} \mathrm{M} \mathrm{CuCl}_{2}^{+}, 1.0 \mathrm{~mL} 7.5 \times 10^{-}$

${ }_{3} \mathrm{M}$ neocuproine, $1.0 \mathrm{~mL} 1 \mathrm{M} \mathrm{NH} 4 \mathrm{Ac}$ buffer solution and $x \mathrm{~mL}$ extract of persimmon and (4$x) \mathrm{mL}$ of diluted water were added and mixed. The mixture was let to stand at room temperature for $30 \mathrm{~min}$. The final absorbance measured at 450 $\mathrm{nm}$ (Shimadzu UV-VIS spectrophotometer). The phenolic antioxidants were estimated as Trolox Equivalents Antioxidant Capacity (TEAC) in this method.

\section{$D P P H^{\bullet}$ assay}

Estimation of DPPH (2,2-diphenyl-1picrylhydrazyl) assay was conducted according to Brand-Williams et al. (1995). Briefly, the DPPH solution was mixed with the standard Trolox solution that prepared at $10,25,50,75$ and $100 \mu \mathrm{L}$ concentrations (the total volume $=4.0 \mathrm{~mL}$ ). The mixture was left in the dark for 5, 10, 15, 20, 25 and $30 \mathrm{~min}$ to determine the maximum and the unchanging absorbance. The absorbance was measured at $515 \mathrm{~nm}$. The results of the assay were calculated in $\mu \mathrm{mol}$ Trolox/g sample.

\section{FRAP assay}

Ferric reducing antioxidant power (FRAP) was conducted according to the method of Benzie and Strain (1996). To prepare the FRAP reagent; 25 $\mathrm{mL}$ of $0.3 \mathrm{~mol} / \mathrm{L}$ acetate buffer ( $\mathrm{pH} 3.6), 2.5 \mathrm{~mL}$ of $20 \mathrm{mmol} / \mathrm{L} \mathrm{FeCl} 3 \times 6 \mathrm{H}_{2} \mathrm{O}$ and $2.5 \mathrm{~mL} 10$ $\mathrm{mmol} / \mathrm{L}$ TPTZ solution in $40 \mathrm{mmol} / \mathrm{L} \mathrm{HCl}$ was mixed cautiously. This solution kept at $37^{\circ} \mathrm{C}$ in a water bath. To analyse, $100 \mu \mathrm{L}$ extracted persimmon samples and $300 \mu \mathrm{L}$ diluted water was mixed with $3 \mathrm{~mL}$ freshly prepared FRAP reagent and incubated at $37^{\circ} \mathrm{C}$ for $40 \mathrm{~min}$. At the end of the time, absorbance was measured at $595 \mathrm{~nm}$. The standard calibration curve was prepared between 10 to $100 \mu \mathrm{mol} / \mathrm{L}$. The results of FRAP assay were expressed as in $\mu \mathrm{mol}$ Trolox/g sample.

\section{Statistical evaluation}

Data obtained from persimmon analyzes were evaluated statistically by using variance analysis with JMP IN 7.0.0 (Statistical Discovery from SAS 2005. Institute Inc., Chicago, USA). The LSD test (Least Significant Differences) was used to determine the statistical difference between the mean values obtained.

\section{RESULTS AND DISCUSSION}

Extractable, non-extractable and total phenolic contents of persimmon samples

The TPC of persimmon samples which is the sum of the phenolic content of EPs and NEPs are presented in Figure 2. According to Figure 2, statistically $(P<0.05)$ significant differences in EPs, NEPs and TPC among the different types were recorded. Sample which is the wild type had the highest TPC (864.85 mg GAE/100g) while the lowest content (220.85 mg GAE/100g) was recorded in the non-astringent type. On the other hand, the TPC of the astringent type was found to be $336.28 \mathrm{mg}$ GAE/100g. Karhan (2003) reported that the level of the TPCs of Fuyu (39.6$84.70 \mathrm{mg} / \mathrm{kg}$ ) which is a non-astringent persimmon type was lower than Hachia (132.05$3745.40 \mathrm{mg} / \mathrm{kg}$ ) which is an astringent persimmon type. In another study TPC of D. lotus (wild persimmon) fruit extract was found to be $130.3 \mathrm{mg} / 100 \mathrm{~g} \mathrm{dw}$ (Murathan, 2020). This result was considerably lower than in the present study. In a previous study carried out by the Kayacan (2020), it was found that the TPC of fresh persimmon was $265.1 \mathrm{mg} \mathrm{GAE} / 100 \mathrm{~g}$. On the other hand, the TPC of persimmon was found to be $364.88 \mathrm{mg}$ GAE/100g by Senica et al (2016). Their results were similar to the present study.

The EPs and NEPs compounds were found to be from 67.81 to $101.22 \mathrm{mg} \mathrm{GAE} / 100 \mathrm{~g}$ and from 137.29 to $766.62 \mathrm{mg}$ GAE/100g, respectively (Figure 2). There were significant $\left(\begin{array}{ll}P & <0.05\end{array}\right)$ differences observed between EPs and NEPs compounds. According to the data obtained from a study published by Imeh and Khokhar (2002), it was reported that these differences could be related to the different varieties, genomics and harvest season of the samples. In this context, the samples of this study were harvested from late 
September to early December. Moreover, samples were different variations in this present study. On the other hand, all these parameters can effect the synthesis and accumulation of phenolic compounds in some parts of the plant (Imeh and Khokhar, 2002).

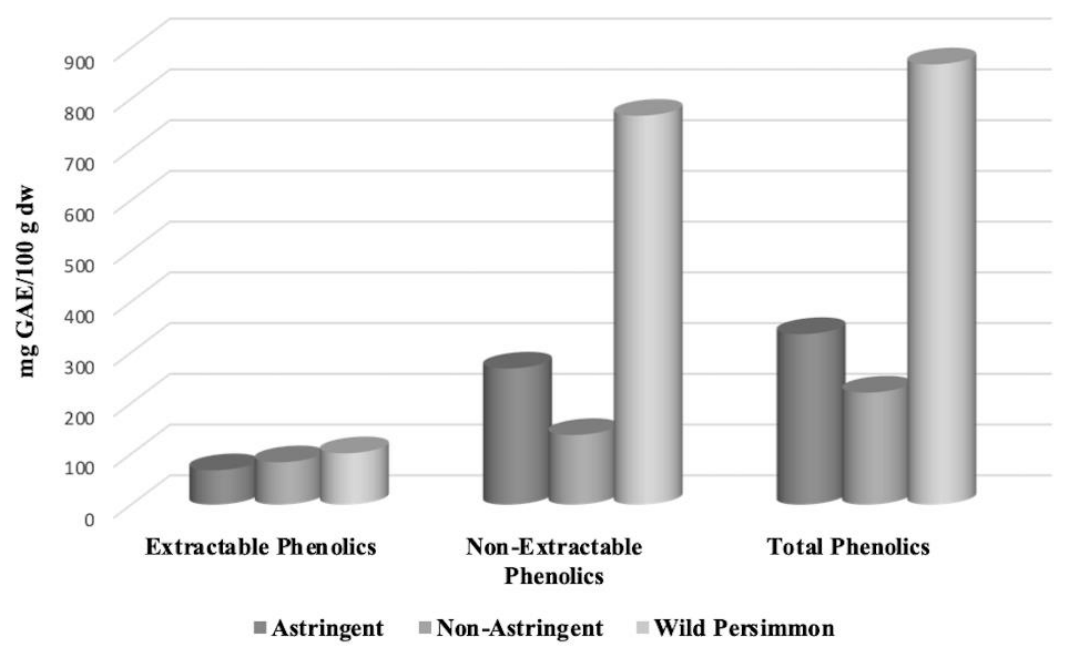

Figure 2. Extractable, non-extractable and total phenolic content of persimmon samples

\section{Bioaccessible phenolics and phenolic} bioaccessibility (\%) of persimmon samples

Bioaccessibility (\%) of phenolic content means that the amount of the phenolic contents which passes through the cell membrane in the intestine. Original phenolic content of food samples is depended to the availability of phenolics within these cells (Gunathilake et al., 2018). In this sense, as reported in the study by Sahan et al. (2017); along with the gastrointestinal digestion, antioxidants may interact with other food components, metabolized or be degraded. Therefore, the evaluation of bioaccessibility is important for a preferable knowledge of the usefulness associated with the consumption of persimmon types.

The contents of bioaccessible phenolics and phenolic bioaccessibility (\%) of persimmon samples are presented in Table 1. Statistically ( $P$ $<0.05)$ significant differences were recorded among the samples. The concentration of bioaccessible phenolics of persimmon samples ranged from 97.23 to $650.83 \mathrm{mg}$ GAE/100g. Although the consumption of non-astringent types of persimmon is preferred by the people, the astringent types have approximately 1.5 fold higher bioaccessible phenolics than the nonastringent types. Another attractive result from this study, although the wild persimmons do not prefer for consumption, the results demonstrated that the bioaccessible phenolics of this type of persimmons were found to be 6.7 fold higher than the non-astringent types and 4.7 fold higher than the astringent types.

Table 1. Bioaccessible phenolics and phenolic bioaccessibility of persimmon samples*

\begin{tabular}{llll}
\hline Samples & & $\begin{array}{l}\text { Bioaccessible Phenolics } \\
(\mathrm{mg} G A E / 100 \mathrm{~g})\end{array}$ & $\begin{array}{l}\text { Phenolic Bioaccessibility } \\
(\%)\end{array}$ \\
\hline Diospyros kaki L. & Astringent & $137.93 \pm 1.21^{\mathrm{b}}$ & $40.99 \pm 3.03^{\mathrm{b}}$ \\
& Non-Astringent & $97.23 \pm 9.96^{\mathrm{c}}$ & $44.29 \pm 6.31^{\mathrm{b}}$ \\
\hline Diospyros lotus L. & Wild Persimmon & $650.83 \pm 1.32^{\mathrm{a}}$ & $75.15 \pm 1.62^{\mathrm{a}}$ \\
\hline
\end{tabular}

*Mean values \pm standard deviation with different superscript in the same row are significantly different $(\mathrm{P}<0.05)$.

GAE $=$ Gallic Acid Equivalents 
The phenolic bioaccessibility (\%) of persimmon samples ranged between from 40.99 to $75.15 \%$. Likewise, the wild persimmons had a higher phenolic bioaccessibility (\%) than the other types of persimmon (Table 1).

\section{Antioxidant capacity of persimmon samples} ABTS $\bullet$, CUPRAC, DPPH• and FRAP methods were used to determine the $\mathrm{AC}$ of persimmon

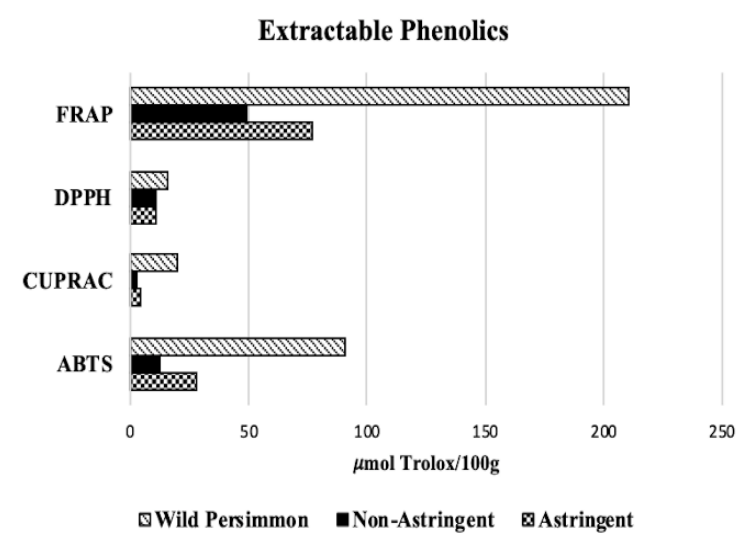

types. The results are presented in Figure 3. In the comparison of the levels of $\mathrm{ABTS}^{*}+$, CUPRAC, DPPH ${ }^{\cdot}$ and FRAP antioxidant capacities among persimmon samples, significant $\left(\begin{array}{ll}P & <0.05\end{array}\right)$ differences were observed in both EPs and NEPs. It is clear that the NEPs were higher than the EPs according to all antioxidant assays.

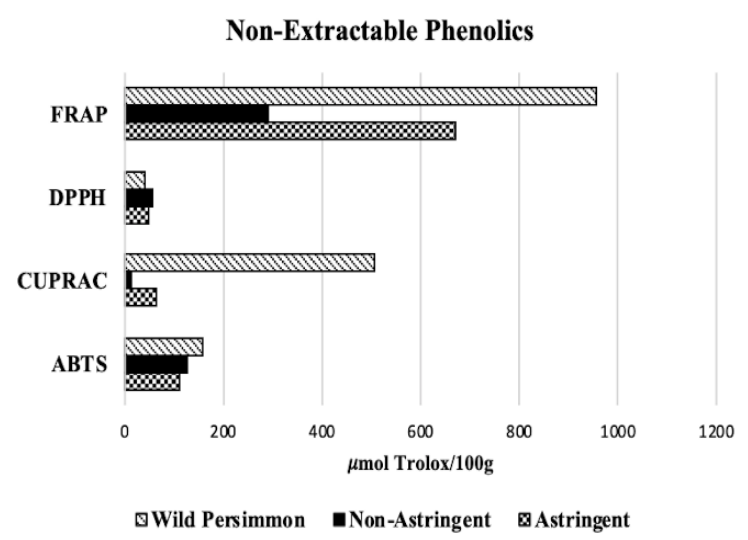

Figure 3. Antioxidant capacities of extractable and non-extractable phenolics of persimmon samples

After the discharged by intestinal microflora fermentation, the NEPs may escape from upper gastrointestinal digestion and are absorbed into the blood plasma. So this bound phenolics that is non-extractable form may have subscribed to more health benefits (Arranz et al., 2009; PérezJiménez and Torres, 2011). In a previous study carried out by Sun et al. (2002), it was reported that almost $24 \%$ of phenolic compounds in fruit still consisted in non-extractable form.

The ABTS ${ }^{\bullet+}$ values were determined between from 109.90 to $158.25 \mu \mathrm{mol}$ Trolox/100g (NEPs) and from 12.86 to $90.64 \mu \mathrm{mol}$ Trolox/100g (EPs) in persimmon samples (Figure 3). The AC of nonastringent type persimmon (Fuyu) was found to be $18.17 \mu \mathrm{mol}$ TEA by Kim et al. (2020). In the study published by Grygorieva et al. (2018), the AC of D. kaki cultivars found to be 47.86-3716.28 $\mu \mathrm{mol} / 100 \mathrm{~g}$. In the same study, the authors reported that the $\mathrm{AC}\left(\mathrm{ABTS}^{-+}\right)$of $D$. virginiana genotypes (American persimmon) ranged from 51.68 to $100.87 \mu \mathrm{mol}$ Trolox/g. Oksuz et al. (2015) investigate the AC of persimmon by
$\mathrm{ABTS}^{\cdot+}$ methods and the result was found to be $364.85 \mathrm{mg}$ TEAC $/ 100 \mathrm{~g}$. In another study, Pu et al. (2013) investigated the AC of D. kaki cultivars by ABTS •+ method from 47.86 to 3716.28 $\mu \mathrm{mol} / 100 \mathrm{~g}$.

In the non-extractable phenolics of CUPRAC values between 13.14 and $506.28 \mu \mathrm{mol}$ Trolox $/ 100 \mathrm{~g}$ were determined, whereas in extractable phenolics were ranged between from 2.56 to $19.67 \mu \mathrm{mol}$ Trolox $/ 100 \mathrm{~g}$ (Figure 3). Kayacan et al. (2020) investigated the AC of fresh persimmon sample by CUPRAC method and the result found to be $635.2 \mathrm{mg}$ TE/ $100 \mathrm{~g} \mathrm{dm}$. In their study, Kim et al. (2020) determined the AC of non-astringent type (Fuyu) persimmon was 29.12 $\mu$ mol TEA.

As can be observed in Figure 3, the AC of the $\mathrm{DPPH}^{\cdot}$ method exhibited lower than the other methods (ABTS $\bullet$, CUPRAC and DPPH*). According to the results, the $\mathrm{AC}$ of nonextractable phenolics ranged from 39.77 to 56.30 $\mu \mathrm{mol}$ Trolox/100g likewise in extractable 
phenolics the values changed between 10.44$16.07 \mu \mathrm{mol}$ Trolox/100g. Pu et al. (2013) evaluated the AC of D. kaki cultivars by $\mathrm{DPPH}^{*}$ method and reported that the results ranged from 190.83 to $2223.11 \mu \mathrm{mol} / 100 \mathrm{~g}$. Kayacan et al. (2020) investigated the AC of fresh persimmon sample by $\mathrm{DPPH} \cdot$ method and the result found to be $299.7 \mathrm{mg}$ TE/100 $\mathrm{g} \mathrm{dm}$. Similar with this results, Oksuz et al. (2015) reported that AC of persimmon that determined by the $\mathrm{DPPH}$ method was $217.60 \mathrm{mg}$ TEAC/100g. In another study, the AC of the persimmon sample was found to be $3.24 \mathrm{mg}$ Trolox eq $/ \mathrm{g} \mathrm{dm}$ (Heras et al. 2017).

In this study, results showed that the AC of the FRAP method exhibited higher than the other methods (ABTS ${ }^{*}$, CUPRAC and DPPH ${ }^{*}$ ) (Figure 3). The non-extractable phenolics of FRAP values were dedicated within the range of 289.84-954.88 $\mu \mathrm{mol}$ Trolox $/ 100 \mathrm{~g}$, whereas in extractable phenolics were 48.97-210.49 $\mu \mathrm{mol}$ Trolox $/ 100 \mathrm{~g}$ in this study. Likewise, Grygorieva et al. (2018) obtained the AC of D. virginiana between 45.06 to $109.30 \mu \mathrm{mol}$ Trolox/g. In another study, Pu et al. (2013) investigated the antioxidant activity of $D$. kaki cultivars by FRAP method found to be from 90.10 to $957.74 \mu \mathrm{mol} / 100 \mathrm{~g}$.
It was found that persimmon types had the highest AC. In the present study, the best AC was detected in the sample of wild persimmon. In the comparison of two types, the $\mathrm{AC}$ of astringent type has been found higher than non-astringent type. In the literature, the persimmon has different concentrations of TPC. This may be due to differences in harvest time, climatic conditions, and methods of analysis.

\section{Bioaccessible antioxidants and bioaccessibility (\%) of antioxidant capacity of persimmon samples}

Table 2 also showed the bioaccessible antioxidants of persimmon samples. According to the Table 2, the bioaccessible antioxidants of ABTS ${ }^{+}$, CUPRAC, DPPH ${ }^{*}$ and FRAP methods represented 65.36-112.95 $\mu \mathrm{mol}$ Trolox/g, 40.02$550.24 \mu \mathrm{mol}$ Trolox/g, 19.18-232.56 $\mu \mathrm{mol}$ Trolox/g and 17.69-542.69 $\mu \mathrm{mol}$ Trolox/g of the initial contents of the samples (Table 2). As can be observed, the bioaccessible antioxidants of wild persimmon were higher than the astringent and non-astringent types. In the study carried out by Kayacan et al. (2020), the bioaccessible TPC and CUPRAC of fresh persimmon was found to be $265.1 \mathrm{mg}$ GAE/100g $\mathrm{dm}$ and $635.19 \mathrm{mg}$ $\mathrm{TE} / 100 \mathrm{~g} \mathrm{dm}$, respectively.

Table 2. Bioaccessible antioxidants of persimmon samples*

\begin{tabular}{|c|c|c|c|c|c|}
\hline \multirow[t]{2}{*}{ Sample } & & \multicolumn{4}{|c|}{$\begin{array}{l}\text { Bioaccessible Antioxidants } \\
(\mu \mathrm{mol} \text { Trolox } / \mathrm{g})\end{array}$} \\
\hline & & ABTS•+ & CUPRAC & DPPH• & FRAP \\
\hline \multirow{2}{*}{ Diospyros kaki L. } & Astringent & $78.02 \pm 2.95^{b}$ & $47.12 \pm 3.61^{b}$ & $22.04 \pm 4.85^{\mathrm{b}}$ & $47.33 \pm 2.57^{b}$ \\
\hline & Non-Astringent & $65.36 \pm 3.62^{c}$ & $40.02 \pm 1.84^{c}$ & $19.18 \pm 3.75^{c}$ & $17.69 \pm 0.34 \mathrm{c}$ \\
\hline Diospyros lotus L. & Wild Persimmon & $112.95 \pm 1.48^{\mathrm{a}}$ & $550.24 \pm 1.30^{\mathrm{a}}$ & $232.56 \pm 3.08^{a}$ & $542.69 \pm 1.84^{a}$ \\
\hline
\end{tabular}

ABTS ${ }^{\bullet}$, CUPRAC, DPPH• and FRAP methods were used to determine the bioaccessibility (\%) of antioxidant capacity of persimmon types and the results are presented in Figure 4.

As can be observed by the results, the bioaccessibility of the astringent and nonastringent persimmon was found to be 56.83 and $67.50 \%$ in ABTS method, respectively. When viewed from the aspect of wild type of persimmon, the bioaccessibility results were found to be $84.14 \%$ (CUPRAC) and $86.05 \%$ (FRAP). This results showed greater than average $50 \%$ antioxidant bioaccessibility. Heras et al. (2017) announced that bioaccessibility (\%) of the total AC of persimmon samples was found to be $33 \%$. 


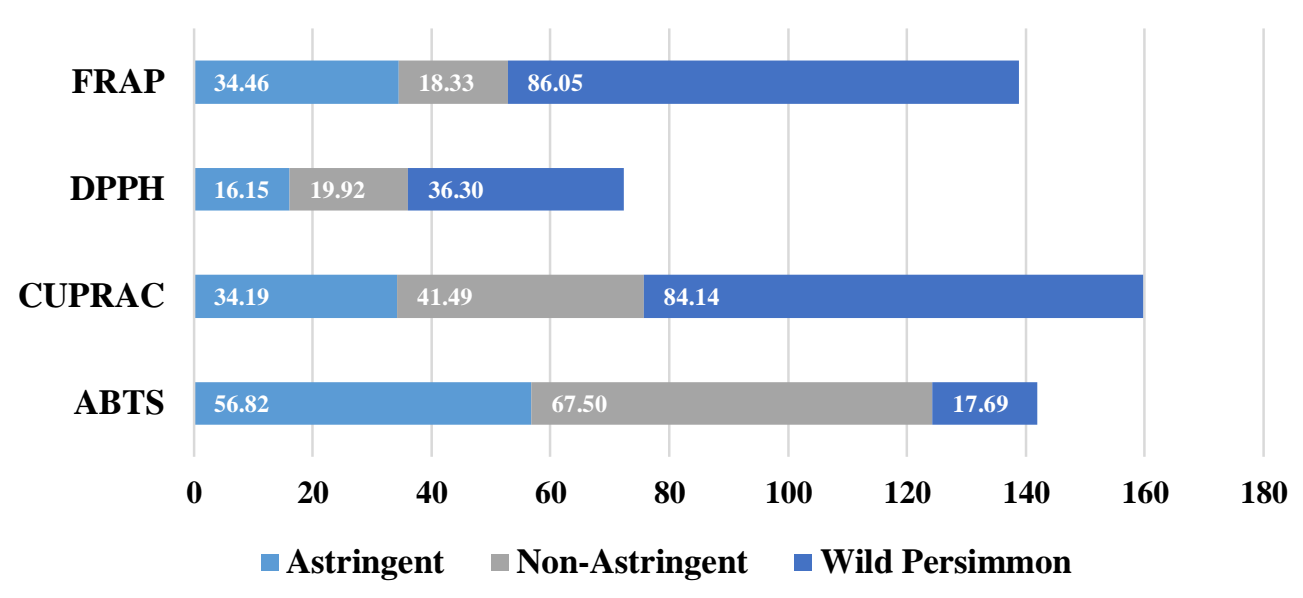

Figure 4. Bioaccessibility (\%) of antioxidant capacity for persimmon samples

\section{CONCLUSION}

In this study, three different types of (astringent, non-astringent and wild) persimmons were applied to determine the effect on antioxidant capacities, TPCs and bioaccessibilities. In this sense, this study was the first evaluation to show the differences between astringent, nonastringent and wild (rootstock) persimmon related to the antioxidant capacities, TPCs and bioaccessibilities. Obtained results demonstrated that all persimmon extracts have a high antioxidant capacity, that associated with the TPC. According to these considerations, the types of persimmons have a great importance both on TPC, antioxidant capacity and bioaccessibility. The results showed that especially the wild type of persimmon is a good source of natural antioxidant. Additionally, it can be concluded from the results that, further studies should be carried out for wild type persimmon.

\section{CONFLICT OF INTEREST}

The author declare no conflict of interest.

\section{REFERENCES}

Anson, N.M., Selinheimo, E., Havenaar R., Aura, A.M., Mattila, I., Lehtinen, P., Bast, A., Poutanen, K., Haenen, G.R.M.M. (2009). Bioprocessing of wheat bran improves in vitro bioaccessibility and colonic metabolism of phenolic compounds. $J$ Agric Food Chem, 57(14): 6148-6155, doi: 10.1021/jf900492h.
Apak, R., Güçü̈, K., Demirata, B., Özyürek, M., C,elik, E.S., Bektaşogłu, B.K., Berker, I., Ö̈yurt, D. (2007). Comparative evaluation of total antioxidant capacity assays applied to phenolic compounds and the CUPRAC Assay. Molecule, 12:1496-1547, doi:10.3390/12071496.

Arranz, S., Saura Calixto, F., Shaha, S., Kroon, P.A. (2009). High contents of nonextractable polyphenols in fruits suggest that polyphenol contents of plant foods have been underestimated. J Agr Food Chem, 57: 7298-7303, doi: 10.1021/jf9016652.

Ayaz, F.A., Kadioglu, A., Reunanen, M. (1997). Changes in phenolic acid contents of Diospyros lotus L. during fruit development. I Agric Food Chem, 45(7):2539-2541, doi:10.1021/jf960741c.

Baytop, T. (1999). Türkşe Bitki Adlar Sözliuğü. Atatürk Kültür, Dil ve Tarih Yüksek Kurumu, Türk Dil Kurumu Yayınlan, No 578, Ankara, 1999, 156 s.

Benzie, I.F.F., Strain, J.J. (1996). The ferric reducing ability of plasma (FRAP) as a measure of antioxidant power: the FRAP assay. Anal Biochem, 239:70-76, doi:10.1006/abio19960292.

Bibi, N., Khattak, A.B., Mehmood, Z. (2007). Quality improvement and shelf life extension of persimmon fruit Diospyros kaki. J Food Eng, 79:1359-63, doi:10.1016/j.jfoodeng.2006.04.016. 
Bölek, S. (2013). Farkli yöntemlerle kurutulmus, trabzon hurmalarının çsşitli kalite karakteristiklerinin kiyaslanması. Celal Bayar Üniversitesi Fen Bilimleri Enstitüsü Gida Mühendisliği Anabilim Dalı Yüksek Lisans Tezi, Manisa, Türkiye, $120 \mathrm{~s}$.

Brand-Williams, W., Cavalier, M.E., Berset, C. (1995). Use of free radical method to evaluate antioxidant capacity. Food Sci Technol, 28(1):25-30, doi:10.1016/S0023-6438(95)80008-5.

Butt, M. S., Sultan, M. T., Aziz, M., Naz, A., Ahmed, W., Kumar, N., Imran, M. (2015). Persimmon (Diospyros kaki) fruit: hidden phytochemicals and health claims. EXCLI Joumal, 14:542-561, doi:10.17179/excli2015-159.

Giordani, E., Doucette, S., Nin, S., Del Bubba, M. (2011). Selected primary and secondary metabolites in fresh persimmon (Diospyros Kaki Thunb.): A review of analytical methods and current knowledge of fruit composition and health benefits. Food Res Int, 44:1752-1767. doi: 10.1016/j.foodres.2011.01.036.

Gorinstein, S., Zemser, M., Weisz, M., Halevy, S., Deutsch, J., Tilus, K., Feintuch, D., Guerra, N., Fishman, M., Bartnikowska, E. (1994). Fluorometric analyses of phenolics in persimmons. Biosci Biotechnol Biochem, 58:10871092. doi:10.1271/bbb.58.1087.

Grygorieva, O., Kucharska, A.Z., Piórecki, N., Klymenko, S., Vergun, O., Brindza, J. (2018). Antioxidant activities and phenolic compounds in fruits of various genotypes of American Persimmon (Diospyros virginiana L.). Acta Sci Pol Technol Aliment, 17(2):117-124, doi: 10.17306/J.AFS.2018.0544.

Gunathilake, K.D.P.P., Ranaweera, K.K.D.S., Rupasinghe, H.P.V. (2018). Change of phenolics, carotenoids, and antioxidant capacity following simulated gastrointestinal digestion and dialysis of selected edible green leaves. Food Chem, 245:371379, doi: 10.1016/j.foodchem.2017.10.096.

Günal N. (2002). Türkiye Doğal Bitki Örtüsünde Relik Bir Tür: Diospyros Lotus L. (Küçük meyveli Trabzon hurmas1). ÖNERI 5(55):237-244.
Harşı1t, B. (2015). Dogu Karadeniz Bölgesı'nde halk arasında tıbbi amaçı kullanilan bazı bitkilerin antioksidan aktivitelerinin incelenmesi. Artvin C,oruh Universitesi Fen Bilimleri Enstitüsü Orman Endüstri Mühendisligi Anabilim Dal1 Yüksek Lisans Tezi, Artvin, Türkiye, 66 s.

Heras, R.M.-L., Pinazo, A., Heredia, A., Andrés, A. (2017). Evaluation studies of persimmon plant (Diospyros kaki) for physiological benefits and bioaccessibility of antioxidants by in vitro simulated gastrointestinal digestion. Food Chem, 214:478-485.

Imeh, U., Khokhar, S. (2002). Distribution of conjugated and free phenols in fruits: antioxidant activity and cultivar variations. J Agr Food Chem, 50(22):6301-6306.

Karhan, M., Artık, N., Özdemir, F. (2003). Changes of major phenolic compounds, major carotenoids and L-Ascorbic acid composition determined by HPLC in persimmon (Diospyros kaki L.) during ripening. GID A 28(4):349-353.

Kayacan, S., Karasu, S., Akman, P.K., Goktas, H., Doymaz, I. (2020). Effect of different drying methods on total bioactive compounds, phenolic profile, in vitro bioaccessibility of phenolic and HMF formation of persimmon. LWT-Food Sci Tecbnol, 118:108830.

Kaplankıran, M. (2011). Subtropik Meyveler II (Ders Notları). Mustafa Kemal Üniversitesi Ziraat Fakültesi Bahçe Bitkileri Bölümü, Hatay (Yayımlanmamıs).

Kim, Y.M., Park, Y.S., Park, Y.K., Ham, K.S., Kang, S.G., Barach, D., Nemirovski, A., Gorinstein, S. (2020). Phytochemical analysis of two main varieties of persimmon and kiwifruit and their antioxidative and quenching capacities. Eur Food Res Tech, 246:1259-1268. doi: 10.1007/s00217-020-03486-z.

Loizzo, M.R., Said, A., Tundis, R., Hawas, U.W., Rashed, K., Menichini, F., Frega, N.G., Menichini, F. (2009). Antioxidant and antiproliferative activity of Diospyros lotus L. extract and isolated compounds. Plant Foods Hum Nutr, 64(4):264-270, doi: 0.1007/s11130-0090133-0. 
Martínez-Calvo, J., Naval, M., Zuriaga, E., Llácer, G., Badenes, M.L. (2013). Morphological characterization of the IVIA persimmon (Diospyros kaki Thunb.) germplasm collection by multivariate analysis. Genetic Resources and Crop Evolution, 60:233-241, doi: 10.1007/s10722-0129828-4.

Macheix, J., Fluriet, A., Billot, J. (1990). Fruit Phenolics. CRC Press, Boca Raton, Florida, USA, $378 \mathrm{p}$.

Mehmood, T., Siddique, F., Malik, S.A., Tabassam, Q., Khan, A.S., Karim, A., Shaheen, M.A. (2016). Antioxidant attributes, phenolics acids composition and biological activity of extracts from japanese persimmon (Diospyros $k a k i)$ as effected by organic solvents and drying technique. Oxid Commun, 39(3):2260-2279.

Messaoudi, Z., Gmili, R.E., Khatib, F., Helmy, Y. (2009). Effect of pollination, fruit thinning and gibberellic acid application on 'Fuyu' kaki fruit development. Acta Hort, 833:233-237. doi:10.17660/ActaHortic.2009.833.37

Mowat, A. (1990). The world scene-production and marketing. In: Collins RJ, (editor). Charting the future. Proceedings of the first national nonastringent persimmon industry workshop, The University of Queensland, Gatton College, 6-7 February, Brisbane, Australia, 37-51p.

Murathan, Z.T. (2020). Phytochemical screening and antioxidant activity of Diospyros Lotus L. fruits grown in Turkey. Acta Sci Pol Hortorum Cultus, 19(2):49-55, doi: 10.24326/asphc.2020.2.5.

Oksuz, T., Surek, E., Tacer-Caba, Z., NiluferErdil, D. (2015). Phenolic contents and antioxidant activities of persimmon and red beet jams produced by sucrose impregnation. Food $S_{c i}$ Technol, 3(1):1-8. doi:10.13189/fst.2015.030101.

Pérez-Jiménez, J., Torres, J.L. (2011). Analysis of nonextractable phenolic compounds in foods: the current state of the art. J Agr Food Chem, 59:1271312724. doi: $10.1021 /$ jf203372w.

Pu, F., Ren, X.L., Zhang, X.P. (2013). Phenolic compounds and antioxidant activity in fruits of six Diospyros kaki genotypes. Eur Food Res Technol, 237:923-932. doi:10.1007/s00217-013-2065-z.
Sahan, Y., Gurbuz, O., Guldas, M., Degirmencioglu, N., Bgenirbas, A. (2017). Phenolics, antioxidant capacity and bioaccessibility of chicory varieties (Cichorium spp.) grown in Turkey. Food Chem, 217:483489. doi:10.1016/j.foodchem.2016.08.108.

Sakakibara, H., Honda, Y., Nakagawa, S., Assida, H., Kanazawa, K. (2003). Simultaneous of all polyphenols in vegetable, fruits and teas. $J A g r$ Food Chem, 51:571-581, doi: 10.1021/jf020926l.

Senica, M., Veberic, R., Grabnar, J.J., Stampar, F., Jakopic, J. (2016). Selected chemical compounds in firm and mellow persimmon fruit before and after the drying process. I Sci Food Agric, 96(9):3140-3147, doi:10.1002/jsfa.7492.

Sun, J., Chu, Y., Wu, X., Liu, R.H. (2002). Antioxidant and antiproliferative activities of common fruits. J Agr Food Chem, 50:7449-7454, doi:10.1021/jf0207530.

Suzuki, T., Someya, S., Hu, F., Tanokura, M. (2005). Comparative study of catechin compositions in five japanese persimmons (Diospyros kaki L.). Food Chem, 93:149-152, doi: 10.1016/j.foodchem.2004.10.017.

Yaqub, S., Farooq, U., Shafi, A., Akram, K., Murtaza, M. A., Kausar, T., Siddique, F. (2016). Chemistry and functionality of bioactive compounds present in persimmon. J Chem, 1-13. doi: $10.1155 / 2016 / 3424025$.

Yeşiloğlu, T., Aka Kacar, Y., Yılmaz, B., İncesu, M., Çimen, B. (2017). Bazı yerli ve yabanc1 Trabzon Hurması (Diospyros kaki L.) çeşit ve tiplerinin morfolojik ve moleküler karakterizasyonu. Türk Tarm-Gıda Bilim ve Teknoloji Dergisi, 5(12):1580-1589.

Yönel, S., Uylașer, V., Yonak, S. (2008). Trabzon hurmasının bileșimi ve besleyici deǧeri. Türkiye 10. G1da Kongresi; 2008 May1s 21-23; Erzurum. s 339-342.

Tuzcu, O., Yıldırım, B. (2000). Trabzon Hurması (Diospyros kaki L.) ve Yetiștiriciliğ. TUBITAK Yayınlar1, TUBITAK Matbaas1, Ankara. 24 s.

Xu, J.G., Tian, C.R., Hu, Q.P., Luo, J.Y., Wang, X.D., Tian, X.D. (2009). Dynamic changes in phenolic compounds and antioxidant activity in 
oats (Avena nuda L.) during steeping and germination, J Agric Food Chem, 57:10392-10398, doi:10.1021/jf902778j.

Vitali, D., Vedrina Dragojević, I., Šebečic, B. (2009). Effects of incorporation of integral raw materials and dietary fibre on the selected nutritional and functional properties of biscuits.
Food Chem, 114:1462-1469, doi: 10.1016/j.foodchem.2008.11.032.

Zheng, Q.L., Nakatsuka, A., Itamura, H. (2006). Involvement of negative feedback regulation in wound induced ethylene synthesis in 'Saijo' persimmon. J Agric Food Chem, 54:5875-9. doi: 10.1021/jf060048h. 